\title{
Exploring COVID-19 Literacy Level among Biology Teacher Candidates
}

\author{
Ahmad Fauzi ${ }^{1}$, H. Husamah ${ }^{1 *}$, Fuad Jaya Miharja ${ }^{1}$, Diani Fatmawati ${ }^{1}$, Tutut Indria Permana ${ }^{1}$, \\ Atok Miftachul Hudha ${ }^{1}$
}

${ }^{1}$ Universitas Muhammadiyah Malang, INDONESIA

Received 1 April 2020 - Accepted 2 May 2020

\begin{abstract}
The specific researches focused on biology teacher candidates in nowadays outbreak/pandemic (COVID-19) condition are very scarce. This study aimed to describe the profile of COVID-19 literacy level possessed by biology teacher candidate students in Indonesia. The data in this survey research was collected between January and March, 2020. The selected location was Malang, one of education city and was announced as the red zone for COVID-19 spread. The total sample were 290 students. The data collection employed the questionnaire, contained of three parts i.e. information of respondent's identity, profile of information resource, attaining time profile of COVID-19 related information, and COVID-19 literacy level. The students' literacy scores were analyzed using ANOVA to analyze the presence of student's years' effect on COVID-19 literacy of biology teacher candidate students. As a result, students' years do not have a significant effect on their COVID-19 literacy. Most students had heard of COVID-19 before the disease was reported to enter Indonesia, but only few students were categorized in high level. The campus should respond immediately to these results, considering that students act as agents of information for those around them.
\end{abstract}

Keywords: biology teacher candidates, COVID-19, health literacy, pandemic

\section{INTRODUCTION}

Coronavirus Disease 2019 (COVID-19) caused by SARS-CoV-2 was firstly reported in Wuhan, Hubei Province, China (Khan, Kazmi, Bashir, \& Siddique, 2020; Li, Yang, \& Ren, 2020; Li, Lu, \& Zhang, 2020; Phan, 2020; Su et al., 2020; Wang et al., 2020). This disease has infected more than a million people throughout the world (Khan et al., 2020; Lin et al., 2020; Worldometers, 2020). World Health Organization designated COVID-19 as global pandemic (Cucinotta \& Vanelli, 2020; LloydSherlock et al., 2020; Mahase, 2020; Sohrabi et al., 2020; Watkins, 2020), so that, officially, the current two global pandemics are HIV/AIDS and COVID-19 (Guessoum, 2020).

Notwithstanding that society possesses its right in accessing the needed information during COVID-19 pandemic, yet format and language barriers of the information are often being constraints for the countries with the low literacy level. The abundant unreliable information (fake news/hoax) which have been greatly spreading exaggerate the confusedness, fear, and irrational behaviors among society (DeLuca, 2020). As the politicized hoax information have been spreading through social media such as WhatsApp, YouTube, Twitter, and Facebook (Adams, 2020; Andrea, 2020; Nussbaumer, 2020; Okan, Sørensen, \& Messer, 2020), "Scientific literacy" is the minimum science essential to be possessed by every citizen in dealing with nowadays' world conditions (DeLuca, 2020). One of whose parts is health literacy.

The society with adequate health literacy owns the awareness of the worst situations occurs, which, in turn, enable them in comprehending the way they must protect themselves and the others through basic treatments. In pandemic situation, the well-informed individual behavior is the main point, besides medical treatment and the accessible governmental policy. Health literacy is crucial determinant in suppressing virus spread rate as considerable as decreasing COVID19 effects (Okan et al., 2020). Moreover, the right and 


\section{Contribution to the literature}

- This study describes the profile of health literacy level in accordance with COVID-19 possessed by biology teacher candidate students in Indonesia.

- The findings of this research are contributed as the reference in formulating steps, plans, and policies in improving society health literacy, especially those are concerned to COVID-19 pandemic.

- Equally important, the findings can be a reference for the next researchers who have the same concern in this topic, particularly in discovering facts, data, policies, and strategies to create a well-prepared society in coping outbreak and pandemic.

valid COVID-19 related information will greatly motivate the world society in sharpening people's insight in cutting edge sciences, particularly, those which related to current epidemiology and virology. Unintentionally, the community has learned a lot about the basics of good science like recognizing data resource features, collecting, verifying, serving, and spreading the data $(\mathrm{Au}, 2020)$. Health literacy, somehow, is a considerable strategy in coping the pandemic issue. The underlying premise of health literacy is that someone will be better prepared to face the disease threat just in case they have good comprehension about the disease they deal with. This concept similarly works on COVID19 (Maverick Insider, 2020).

The limited or inadequate literacy affects to the decrease of protective behavior adoption (CastroSánchez, Chang, Vila-Candel, Escobedo, \& Holmes, 2016). A study case in Europe showed that health literacy in a challenge for neglected society. More than one third citizens facing obstacles in discovering, understanding, evaluating, and utilizing information in managing their health. People with poor health literacy are more at risk of being infected by COVID-19 (Okan et al., 2020; Sørensen, 2020). Since the correlation between poor health literacy and deprived health issue is significant, hence, health literacy concept is critical. Having lack of detail understanding, people will spread unconfirmed information greatly, which, as the qonsequences, they make detrimental decision for themselves and surrounding people (DeWalt, Berkman, Sheridan, Lohr, \& Pignone, 2004; Sørensen et al., 2012). The low level of health literacy also affect the worst health status, bad comprehension of medical condition, medical information and preventive health services, as depraved as the increase of hospitalization rate and advance health care cost (Batterham, Beauchamp, \& Osborne, 2016; Griffey, Kennedy, McGownan, Goodman, \& Kaphingst, 2014; MacLeod et al., 2017; McCray, 2005).

People with low levels of health literacy (manifested in the form of unhealthy lifestyles), mostly are people with low education, low economy, and older people (Mullan et al., 2017; Pampel, Krueger, \& Denney, 2010; Protheroe et al., 2017). Take Busan, Korea, as the case study, in Busan, the senior citizens (over 50 years old) are at risk group of society (Fendos, 2020). Health literacy influences individual factor and condition, health service response, as well as health service providers and organizations. Aside of their background and education, many people find hindrances in navigating health care system and often unable to understand the given information from health service providers and organizations (Lima, Vasconcelos, \& Borba, 2019; Mullan et al., 2017; Peters, 2017).

As the future leaders, recent young generation need to learn how to proceed scientific information and strengthen their empathy. Not only do they need to comprehend basic science concepts, but they are also required to possess reading and scientific information processing skills, besides making healthy decisions based on the information obtained (Budd, 2020). This has been challenges for the educators throughout the world (Schwartz, 2020). It is compulsory need to improve society health literacy. This kind of intervention of society health issue are potentially diminish incidence and death rate (Albright \& Allen, 2018).

Acknowledging the lack of empirical supports among society, many scientists conducted several researches related to health literacy among students. Some of them addressed medical students (Kaper et al., 2020; Štefková, Čepová, Kolarčik, \& Madarasová Gecková, 2018), nursing student (Ayaz-Alkaya \& Terzi, 2019; Balmer, King, Moloney, Moselen, \& Dixon, 2020; George \& DeCristofaro, 2018; Ozen, Bal Ozkaptan, Coskun, \& Terzioglu, 2019), pharmacy students (Mnatzaganian, Fricovsky, Best, \& Singh, 2017; Newsome, Mallawaarachchi, Conklin, \& Ray, 2018), military college students (Rong et al., 2017), as well and general students (Barsell, Everhart, Miadich, \& Trujillo, 2018; Elsborg, Krossdal, \& Kayser, 2017; Mackert, Champlin, \& Mabry-Flynn, 2017; Matthews, 2018; Rababah, Al-Hammouri, Drew, \& Aldalaykeh, 2019; Rosario et al., 2017; Runk, Durham, Vongxay, \& Sychareun, 2017; Sukys, Cesnaitiene, \& Ossowsky, 2017; Uysal, Ceylan, \& Koç, 2020). However, the specific researches focused on teacher candidate students, particularly biology teacher candidates in nowadays outbreak/pandemic condition are very scarce. Yet teachers play an important role in culturing health literacy (Denuwara \& Gunawardena, 2017; Sormunen, Goranskaya, Kirilina, Bykachev, \& Tossavainen, 2018) which should be gained and implemented in various setting (Vamos, Okan, Sentell, \& Rootman, 2020). Several 
studies showed that health and learning are interrelated fields (Peterson, Cooper, \& Laird, 2001). These fields influence student's health understanding, health lifestyle, and so forth (Lamanauskas \& Augiene, 2020). Teachers' motivations and competencies, someway, determine learning effectiveness and their ability in promoting health literacy to their students (Lai, Wu, Lee, \& Jhang, 2018). For this very reason, in today's outbreak situation, the role of education field is vital (Bakhtiar, 2016; Barennes, Harimanana, Lorvongseng, Ongkhammy, \& Chu, 2010; Karlsen, Mehli, Wahl, \& Staberg, 2015; Pogreba-Brown, Ernst, \& Harris, 2012; Yang, Park, Lee, \& Lee, 2019).

Therefore, this study aimed to describe the profile of health literacy level in accordance with COVID-19 possessed by biology teacher candidate students in Indonesia. The findings of this research are contributed as the reference in formulating steps, plans, and policies in improving society health literacy, especially those are concerned to COVID-19 pandemic. Equally important, the findings can be a reference for the next researchers who have the same concern in this topic, particularly in discovering facts, data, policies, and strategies to create a well-prepared society in coping outbreak and pandemic.

\section{METHODS}

\section{Study Design}

This survey research was designed to explore students' COVID-19 literacy level. This research was conducted by involving the students of the greatest private university in Indonesia. The data was collected between January and March, 2020. In this period, COVID-19 outbreak has been reported entered Indonesia. The universities have been instructed to conduct online learning, yet the students were instructed not to go home (to their hometown).

\section{Study Site and Sample Selection}

The selected location for this research was Malang, East Java, Indonesia. Malang is one of education city in Indonesia and was announced as the red zone for COVID-19 spread in Indonesia. The research sample were all students of Faculty of Teacher Training and Education in one of private university in Malang. The total sample were 290 students which comprised of 76 students of year 2016, 85 students of year 2017, 80 students of year 2018, and 49 students of year 2019 .

\section{Data Collection Instrument}

The data collection of COVID-19 literacy employed the questionnaire which was designed by the researchers. The questionnaire contained of three parts i.e. information of respondent's identity, profile of information resource, attaining time profile of COVID-
19 related information, and COVID-19 literacy level. To be more detail, the literacy level part comprised of four aspects asked, i.e. (1) disease spread and transmission; (2) causes and disease symptoms; (3) prevention of spread and disease transmission; and (4) treatment and death rate. The total of item asked in this part were 21 items. By considering Malang condition during the research held, the questionnaire was transformed into online questionnaire by utilizing Google Form platform. The online questionnaire link was spread to the respondents in term of Biology Education students.

\section{Data Analysis}

The survey data gained was downloaded in .csv format which was then checked by researchers before the analysis process. The analysis was aided using Microsoft Excel and SPSS softwares. Data frequency of the information resource profile was calculated and presented in radar graphic form. Meanwhile, the data of attaining time profile of COVID-19 related information were converted into 0 and 1 scores, where, 0 represented "No" response and 1 represented "Yes" response. Similarly, the data of literacy level were also converted into 0 and 1 scores, in which, each of the wrong answer was given 0 score, while the right answer was given 1 score. Meanwhile, in case, the respondents chose "No Idea", this was recognized as wrong answer. The undergirding reason for the categorization of "No Idea" as wrong answer was as the respondents chose "No Idea", this indicated that the respondents lack of knowledge about the stated information. Implementing "No Idea" response is a conservative strategy.

Furthermore, the data of attaining time profile of COVID-19 related information as well as the data of COVID-19 literacy level were presented through crosstab. The Chi-square analysis was held to ensure the existence of significant association between the differences of student's year variable and students' response toward the asked information. FisherFreeman-Halton exact test was used when the cell with the total number of the data less than five. The score of 21 items in literacy level were summed as the literacy score of each student. Student literacy level was grouped as "good", "moderate", or "low" based on Bloom cut-off point. When the students were able to give their response properly toward minimum $80 \%$ of the asked information, she/he was categorized as "good" in literacy level. Meanwhile if the properness of the response given was between 60 and $79 \%$, the students were grouped as "moderate", and the "low" level literacy category was given to the students who gave proper response less than $60 \%$ of the asked information. The frequency of the three literacy group levels of each student's year were then served in pie chart. Furthermore, the students' literacy scores were analyzed using one-way analysis of variance (ANOVA) to analyze 
(a) sources read/heard by respondents

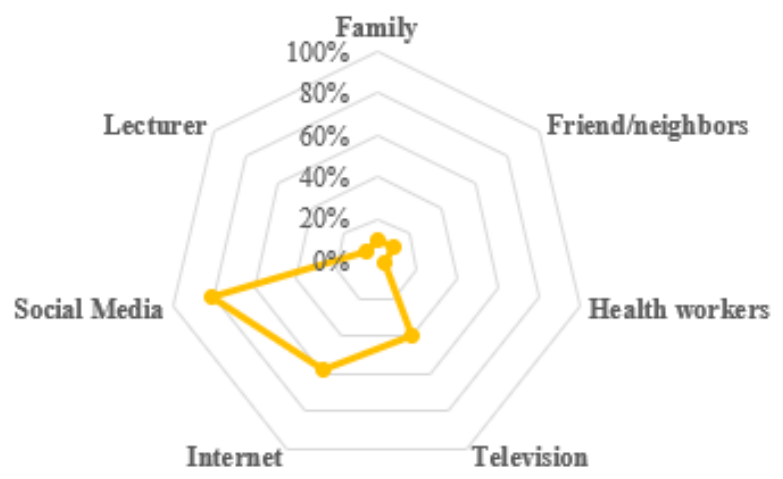

(b) Sources trusted by respondents

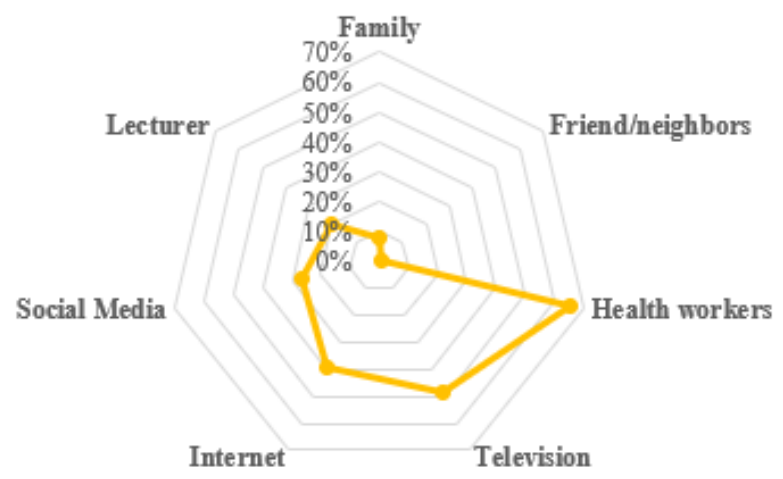

Figure 1. The profile of source types which inform COVID-19 related information: (a) sources read/heard by respondents; (b) sources trusted by respondents ( $n=290$, each respondent was allowed to choose more than one options)

the presence of student's years' effect on COVID-19 literacy of biology teacher candidate students.

\section{RESULTS AND DISCUSSION}

\section{The Profile of Information Resource}

This research explored the literacy level of biology teacher candidate students about COVID-19. The students need information resource to comprehend this novel disease. Social media has been the most popular information source provides the information about COVID-19 for them. As of 38\% students gained COVID19 related information from social media (Figure 1), while internet and television were placed in the second $(28 \%)$ and third position $(19 \%)$ as the chosen resources. Nevertheless, Figure 1 also indicates that only 13\% students who trusted the information validity obtained from social media. Health workers were the most reliable source for the students $(31 \%)$, followed by television news (23\%) and internet (19\%). Interestingly, although the most reliable source for most of the students was health workers, yet, only $2 \%$ of the students who obtained the COVID-19 related information from this source.

The research results showed that biology teacher candidate students were able to access/obtain health information. They were able to determine the reliable information source, even though they tended to choose the easiest reached source in term of social media. It is unavoidable that the nowadays' digital advancement has led the social media to be popular among young generation (Halsall, Garinger, Dixon, \& Forneris, 2019; Moon \& Bai, 2020; Tezci \& İçen, 2017). Social media, as the "fancy" recognized technology, attracts its user attention (Oelze, 2019). Likewise, the interesting visualization of social media (through the combination of text, image, video, and audio) motivates the students to gain the great amount of information (Oelze, 2019; Paulsen \& Taekke, 2013; Tezci \& İçen, 2017).
Nonetheless, the use of social media also risks the emergence of misinformation as the hyperbole language used in this source, thus, to find accurate online information become hindrance (Adams, 2020; Khan \& Idris, 2019; Nussbaumer, 2020; Tully, Vraga, \& Bode, 2020; Vraga \& Tully, 2019). Based on the data, there were $31 \%$ biology teacher candidate students who implied that the reliable information source for them about COVID-19 was not social media but health workers (Figure 1). They performed their ability in choosing the proper and reliable information. This is a good finding in term of students' literacy level. According to Sørensen et al. (2012), one of the abilities possessed by individual with the high literation level is assessing health information if the information right or not. Chen et al. (2018) reported that people with low literation level tend to trust the information source like television and social media compared to health workers. Hence, it is clear that the advance of digital era demands specific literacy skills of technology users so that they can control and utilize the information provided, including COVID-19 related information.

\section{The Profile of Information Attaining Time}

Table 1 informs the time the teacher candidate students attained the COVID-19 related information. As many as $89.7 \%$ students have heard about COVID-19 before the first patient report found in Indonesia. As of 90.3\% students gained the information about the prevention procedure of the disease transmission. However, only $56.2 \%$ students have gained the information about travelling protocol in COVID-19 pandemic situation. The percentage of students who have heard about the information of prevention procedure of the disease transmission was the only profile which was significantly associated with the student's year $(P<0.05)$. 
Table 1. The profile of COVID-19 related information attaining time of biology teacher candidate students

\begin{tabular}{|c|c|c|c|c|c|c|}
\hline \multirow{2}{*}{ Item } & \multicolumn{4}{|c|}{ Student's Year } & \multirow{2}{*}{ Total n (\%) } & \multirow{2}{*}{ P-value } \\
\hline & $2016 \mathrm{n}(\%)$ & 2017 n (\%) & $2018 \mathrm{n}(\%)$ & $2019 \mathrm{n}(\%)$ & & \\
\hline \multicolumn{6}{|c|}{ Heard that COVID-19 has entered Indonesia } & 0.287 \\
\hline Yes & $70(92.1)$ & $79(92.9)$ & $70(87.5)$ & $41(83.7)$ & $260(89.7)$ & \\
\hline No idea & $6(7.9)$ & $6(7.1)$ & $10(12.5)$ & $8(16.3)$ & $30(10.3)$ & \\
\hline \multicolumn{6}{|c|}{ Heard about the preventive procedure of COVID-19 transmission } & $0.039^{*}$ \\
\hline Yes & $65(85.5)$ & $75(88.2)$ & $78(97.5)$ & $44(89.8)$ & $262(90.3)$ & \\
\hline No idea & $11(14.5)$ & $10(11.8)$ & $2(2.5)$ & $5(10.2)$ & $28(9.7)$ & \\
\hline \multicolumn{6}{|c|}{ Heard about preventive protocol of COVID-19 transmission during travelling } & 0.701 \\
\hline Yes & $42(55.3)$ & $47(55.3)$ & $49(61.3)$ & $25(51.0)$ & $163(56.2)$ & \\
\hline No idea & $34(44.7)$ & $38 * 44.7)$ & $31(38.6)$ & $24(49.0)$ & $127(43.8)$ & \\
\hline
\end{tabular}

The all P-values were based on Chi-square analysis except those with the asterisk mark $\left(^{*}\right)$ which were based on Fisher-Freeman-Halton exact test

Table 2. The literacy level of biology teacher candidate students about COVID-19

\begin{tabular}{|c|c|c|c|c|c|c|}
\hline \multirow{2}{*}{ Asked aspect } & \multicolumn{4}{|c|}{ Student's Year } & \multirow{2}{*}{ Total n (\%) } & \multirow{2}{*}{ P-value } \\
\hline & $2016 \mathrm{n}(\%)$ & 2017 n $(\%)$ & $2018 \mathrm{n}(\%)$ & $2019 \mathrm{n}(\%)$ & & \\
\hline \multicolumn{7}{|c|}{ Disease spread and transmission } \\
\hline \multicolumn{6}{|c|}{ Possible infected area } & \multirow[t]{3}{*}{$0.565^{*}$} \\
\hline Proper & $72(94.7)$ & $83(97.6)$ & $75(93.8)$ & $46(93.9)$ & $276(95.2)$ & \\
\hline Improper & $4(5.3)$ & $2(2.4)$ & $5(6.3)$ & $3(6.1)$ & $14(4.8)$ & \\
\hline \multicolumn{6}{|c|}{ Possible infected people } & \multirow[t]{3}{*}{$0.766^{*}$} \\
\hline Proper & $74(97.4)$ & $83(97.6)$ & $79(98.8)$ & $49(100)$ & $285(98.3)$ & \\
\hline Improper & $2(2.6)$ & $2(2.4)$ & $1(1.3)$ & $0(0)$ & $5(1.7)$ & \\
\hline \multicolumn{6}{|c|}{ Transmission ways } & \multirow[t]{3}{*}{0.411} \\
\hline Proper & $11(14.5)$ & $19(22.4)$ & $19(23.8)$ & $8(16.3)$ & $57(19.7)$ & \\
\hline Improper & $65(85.5)$ & $66(77.6)$ & $61 * 76.3)$ & $41(83.7)$ & $233(80.3)$ & \\
\hline \multicolumn{6}{|c|}{ Possible infection from cured patient } & \multirow[t]{3}{*}{0.259} \\
\hline Proper & $14(18.4)$ & $17(20.0)$ & $17(21.3)$ & $16(32.7)$ & $64(22.1)$ & \\
\hline Improper & $62(81.6)$ & $68(80.0)$ & $63(78.8)$ & $3367.3)$ & $226(77.9)$ & \\
\hline \multicolumn{6}{|c|}{ Transmission level } & \multirow[t]{3}{*}{0.563} \\
\hline Proper & $6889.5)$ & $70(82.4)$ & $67(83.8)$ & $43(87.8)$ & $248(85.5)$ & \\
\hline Improper & $8(10.5)$ & $15(17.6)$ & $13(16.3)$ & $6(12.2)$ & $42(14.5)$ & \\
\hline
\end{tabular}

The next finding showed that the biology teacher candidate students were able to behave proactive in gaining COVID-19 related information. This has also been influenced by social media. In fact, the nowadays' social media has been massively proliferated and are able to eliminate time and place barriers (Al-Aufi, AlAzri, \& Al-Hadi, 2017; M. L. Khan \& Idris, 2019; Moon \& Bai, 2020). Hence, this enables the students to access COVID-19 related information which has been pandemic in many countries. Khan and Idris (2019) stated that the obtaining information skill must be accompanied with individual information literacy, this due to the crucially in verifying the gained information to avoid the continuous widespread of wrong information. Based on the research results obtained, it can be inferred that the biology teacher candidate students were fairly active in seeking and accessing health information. This ability is also considered as one of health literacy (Sørensen et al., 2012). The credibility of information source is the main factor determines the health literacy of young generation (Ghaddar, Valerio, Garcia, \& Hansen, 2012).

The student's year has significantly associated with the percentage of students who have heard the information about the preventive procedure of COVID-
19 transmission. This was assumed to be correlated with students' age and cognitive maturity. The research findings of Duong et al. (2018) proved that people's age determines their literacy level. In accordance with cognitive maturity, Tavakoly Sany, Peyman, Zadehahmad, Ferns, and Doosti (2019) argued that this is one of determinant factors for someone's literacy. In the other words, the high cognitive level leads someone to be able to control and determine proper behaviors related to his/her healthy, including the way to prevent COVID-19 transmission.

\section{The COVID-19 Literacy of Biology Teacher Candidate Students}

Table 2 summaries the profile of biology teacher candidate students' COVID-19 literacy. The majority students understood that everybody has the possibility to be infected by COVID-19 (98.3\%). Likewise, they knew that the person who has contacted with the COVID-19 infected person must be isolated (95.9\%). As many as 276 students understood that the COVID-19 infected people can be cured (95.2\%). On the other hand, there were only 17 students who possessed proper concept about the role pf vaccine (5.9\%), no more than 29 students (10.0\%) who could identify COVID-19 
Table 2 (continued). The literacy level of biology teacher candidate students about COVID-19

\begin{tabular}{|c|c|c|c|c|c|c|}
\hline \multirow{2}{*}{ Asked aspect } & \multicolumn{4}{|c|}{ Student's Year } & \multirow{2}{*}{ Total n (\%) } & \multirow{2}{*}{ P-value } \\
\hline & $2016 \mathrm{n}(\%)$ & $2017 \mathrm{n}(\%)$ & 2018 n (\%) & 2019 n (\%) & & \\
\hline \multicolumn{7}{|c|}{ Cause and symptom } \\
\hline \multicolumn{6}{|c|}{ Cause identification } & \multirow[t]{3}{*}{0.045} \\
\hline Proper & $64(84.2)$ & $79(92.9)$ & $69(86.3)$ & $48(98.0)$ & $260(89.7)$ & \\
\hline Improper & $12(15.8)$ & $6(7.1)$ & $11(13.8)$ & $1(2)$ & $30(10.3)$ & \\
\hline \multicolumn{6}{|c|}{ Symptom identification } & \multirow[t]{3}{*}{$0.084^{*}$} \\
\hline Proper & $8(10.5)$ & $14(16.5)$ & $4(5.0)$ & $3(6.1)$ & $29(10.0)$ & \\
\hline Improper & $68(89.5)$ & $71(83.5)$ & $76(95.0)$ & 46 93.9) & $261(90.0)$ & \\
\hline \multicolumn{6}{|c|}{ Symptoms emergence on infected person } & \multirow[t]{3}{*}{0.277} \\
\hline Proper & $49(64.5)$ & $48(56.5)$ & $44(55.0)$ & $23(46.9)$ & $164(56.6)$ & \\
\hline Improper & $27(35.5)$ & $37(43.5)$ & $36(45.0)$ & $26(53.1)$ & $126(43.4)$ & \\
\hline \multicolumn{7}{|c|}{ Spread and transmission prevention } \\
\hline \multicolumn{6}{|c|}{ Identification of self-protection } & \multirow[t]{3}{*}{0.052} \\
\hline Proper & $39(51.3)$ & $35(41.2)$ & $49(61.3)$ & $29(59.2)$ & $152(52.4)$ & \\
\hline Improper & $37(48.7)$ & $50(58.8)$ & $31(38.8)$ & $20(40.8)$ & $138(47.6)$ & \\
\hline \multicolumn{6}{|c|}{ Self-protection through the utilization of hot and salt waters for bathing } & \multirow[t]{3}{*}{0.017} \\
\hline Proper & $33(43.4)$ & $28(32.9)$ & $19(23.8)$ & $10(20.4)$ & $90(31.0)$ & \\
\hline Improper & $43(56.6)$ & $57(67.1)$ & $61(76.3)$ & $39(79.6)$ & $200(69.0)$ & \\
\hline \multicolumn{6}{|c|}{ Avoiding physical contact with patient } & \multirow[t]{3}{*}{0.586} \\
\hline Proper & $49(64.5)$ & $62(72.9)$ & $58(72.5)$ & $36(73.5)$ & $205(70.7)$ & \\
\hline Improper & $27(35.5)$ & $23(27.1)$ & $22(27.5)$ & $13(26.5)$ & $85(29.3)$ & \\
\hline \multicolumn{6}{|c|}{ Avoiding body fluids of infected people } & 0.734 \\
\hline Proper & $54(71.1)$ & $61(71.8)$ & $61(76.3)$ & $33(67.3)$ & $209(72.1)$ & \\
\hline Improper & $22(28.9)$ & $24(28.2)$ & $19(23.8)$ & $16(32.7)$ & $81(27.9)$ & \\
\hline Isolation compu & r people with & $m s$ & & & & $0.319^{*}$ \\
\hline Proper & $71(93.4)$ & $75(88.2)$ & $76(95.0)$ & $47(95.9)$ & $269(92.8)$ & \\
\hline Improper & $5(6.6)$ & $10(11.8)$ & $4(5.0)$ & $2(4.1)$ & $21(7.2)$ & \\
\hline Isolation period & & & & & & $0.05^{*}$ \\
\hline Proper & $68(89.5)$ & $75(88.2)$ & $74(92.5)$ & $49(100)$ & $266(91.7)$ & \\
\hline Improper & $8(10.5)$ & $10(11.8)$ & $6(7.5)$ & $0(0.0)$ & $24(8.3)$ & \\
\hline Isolation compu & r infected cont & seople & & & & $0.508^{*}$ \\
\hline Proper & 75 (98.7) & $80(94.1)$ & $76(95.0)$ & 47 (95.9) & $278(95.9)$ & \\
\hline Improper & $1(1.3)$ & $5(5.9)$ & $4(5.0)$ & $2(4.1)$ & $12(4.1)$ & \\
\hline Treatment and & & & & & & \\
\hline The infected pec & be cured & & & & & $0.671^{*}$ \\
\hline Proper & 73 (96.1) & 79 (92.9) & $76(95.0)$ & $48(98.0)$ & $276(95.2)$ & \\
\hline Improper & $3(3.9)$ & $6(7.1)$ & $4(5.0)$ & $1(2.0)$ & $14(4.8)$ & \\
\hline Vaccine role & & & & & & $0.682^{*}$ \\
\hline Proper & $6(7.9)$ & $3(3.5)$ & $5(6.3)$ & $3(6.1)$ & $17(5.9)$ & \\
\hline Improper & $70(92.1)$ & $82(96.5)$ & $75(93.8)$ & 46 (93.9) & $273(94.1)$ & \\
\hline Antivirus role & & & & & & 0.384 \\
\hline Proper & $21(27.6)$ & $19(22.4)$ & $18(22.5)$ & $7(14.3)$ & $65(22.4)$ & \\
\hline Improper & $55(72.4)$ & 66 (77.6) & $62(77.5)$ & $42(85.7)$ & $225(77.6)$ & \\
\hline Traditional hea & & & & & & 0.539 \\
\hline Proper & $68(89.5)$ & 71 (83.5) & 65 (81.3) & $41(83.7)$ & 245 (84.5) & \\
\hline Improper & $8(10.5)$ & $14(16.5)$ & $25(18.8)$ & $816.3)$ & 45 (15.5) & \\
\hline Spiritual healin & & & & & & 0.355 \\
\hline Proper & $38(50.0)$ & $46(54.1)$ & $42(52.5)$ & $19(38.8)$ & $145(50.0)$ & \\
\hline Improper & $38(50.0)$ & $39(45.9)$ & 38 (47.5) & $30(61.2)$ & $145(50.0)$ & \\
\hline Death rate & & & & & & 0.638 \\
\hline Proper & $18(23.7)$ & $26(30.6)$ & $18(22.5)$ & $12(24.5)$ & $74(25.5)$ & \\
\hline Improper & 58 (76.3) & $59(69.4)$ & $62(77.5)$ & $37(75.5)$ & $216(74.5)$ & \\
\hline
\end{tabular}

The all P-values were based on Chi-square analysis except those with the asterisk mark $\left(^{*}\right)$ which were based on Fisher-Freeman-Halton exact test

symptoms, and only small number of students $(19.7 \%)$ who could identify transmission method of COVID-19. Of the knowledge about COVID-19 asked, there only knowledge about the cause of COVID-19, the role of hot and salt waters on self-protection toward COVID-19, and the isolation period were significantly associated with student's year $(P<0.05)$.

\section{COVID-19 Literacy Level}

Figure 2 depicts the COVID-1 literacy level of biology teacher candidate students. It was only the minority students who have high literacy level. The students with high literacy level in student's years of 2016, 2017, 2018, and 2019 were only $4 \%, 1 \%, 6 \%$, and $4 \%$ respectively. 

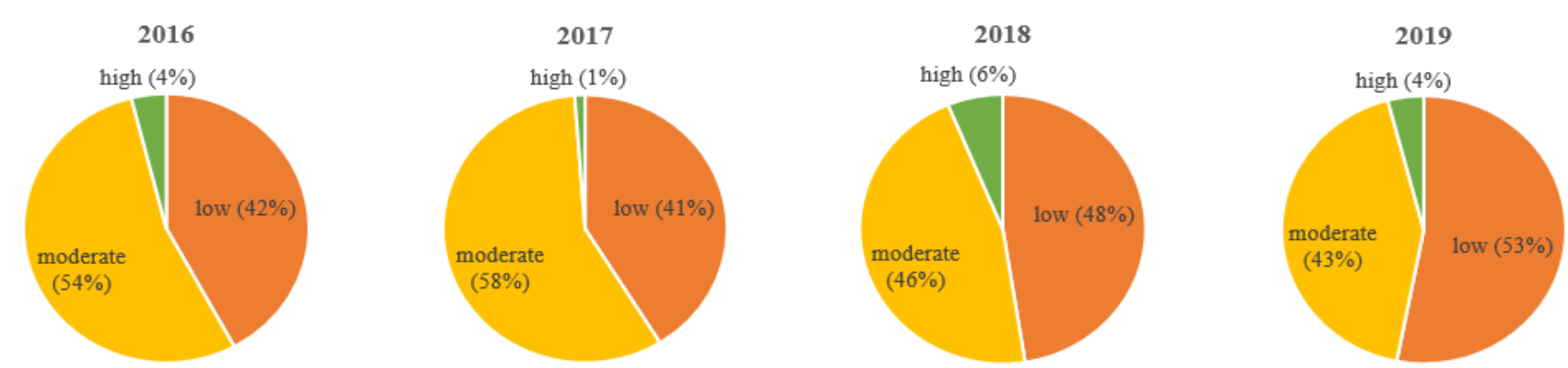

Figure 2. The different profile of literacy level of biology teacher candidate students based on four student's years

Table 3. The summary of one-way ANOVA analysis results of the effect of study period on COVID-19 literacy level of Biology Education students

\begin{tabular}{lcccccc}
\hline Source & Type III Sum of Squares & Df & Mean Square & F & Sig. & Partial Eta Squared \\
\hline Corrected Model & $1.904^{a}$ & 3 & 0.635 & 0.121 & 0.948 & 0.001 \\
Intercept & 44370.492 & 1 & 44370.492 & 8424.497 & 0.000 & 0.967 \\
Student's year & 1.904 & 3 & 0.635 & 0.121 & 0.948 & 0.001 \\
Error & 1506.317 & 286 & 5.267 & & & \\
Total & 48054.000 & 290 & & & & \\
Corrected Total & 1508.221 & 289 & & & & \\
\hline
\end{tabular}

a. R Squared $=.001$ (Adjusted R Squared $=-.009$ )

Yet, the majority students of student's years 2016 and 2017 were categorized in moderate level (i.e. 54\% and $58 \%$ in sequence) and considerably, the majority students in student's years of 2010 (48\%) and 2019 (53\%) were grouped in low level.

The third finding of this research showed that the teacher candidate students could understand the COVID-19 related information. This in line with several research findings which reported that the individual with high level of health literacy could gain, comprehend, assess and use health information properly and relevant (DeWalt et al., 2004; Ranaweera, 2017; Sørensen et al., 2012). However, literally, not all information obtained by students could be encompassed properly such as the transmissions, symptoms, and the role of vaccine in COVID-19 pandemic situation. This fact shows that the biology teacher candidate students did not yet deserve to be called as health literate people. This finding is supported by the other finding of this research which showed the low literacy level of biology teacher candidate students about COVID-19 (Figure 2). This can be caused by various factors one of which is students' academic ability (Banik \& Kumar, 2019; Erich \& Popescu, 2010; Shao \& Purpur, 2016; Soleymani, 2014). The individuals with high academic ability level are able to get the point and verify the rightness of information gained (Karimi, Ashrafi-Rizi, Papi, Shahrzadi, \& Hassanzadeh, 2015; Sykes, Wills, Rowlands, \& Popple, 2013; Wolf et al., 2012). Additionally, the students were keen on access social media to obtain information (Figure 2), and were not accustomed to gain the valid and credible information sources. Yet credible information source is the main factor affect individual literacy (Chen et al., 2018; Ghaddar et al., 2012). Chen et al. (2018) stated that the low individual literacy skill is indicated by the use of social media as their information source. The students still need further guidance to have good information literacy so that they can construct coherent arguments. Thus, the improvement of teacher candidate students' literacy skill, particularly health literacy, in COVID-19 pandemic situation is the critical aspect to be considered by the LPTK (Lembaga Pendidikan Tenaga Kependidikan-Teacher Training Institute) in Indonesia.

\section{The Influence of Student's Year on COVID-19 Literacy}

Table 3 presents the results of one-way ANOVA test of the influence of student's year on students' COVID-19 literacy. It informs that student's year paid significant effect to their literacy level $[F(3,286)=0.121, P=0.948$, $\left.\eta \mathrm{p}^{2}=0.001\right]$

The last finding of this research showed that the students of different student's years (2016, 2017, 2018, and 2019) owned almost similar level of COVID-19 literacy which was categorized as low. In the other words, even though they possessed different basic science (as their different years), yet they were unable to, entirely, access, understand, assess, and utilize COVID19 related information properly. This low level of students' health literacy can possibly cause by the lack empowerment of the ability in student learning process in Indonesia. Health literacy, somehow, is strongly correlated with education process in school (Gazmararian, Curran, Parker, Bernhardt, \& DeBuono, 2005; Kickbusch \& Maag, 2008; Peterson et al., 2001). Health literacy can be constructed as students are accustomed to integrate reading, writing (Genlott \& Grönlund, 2013), interpreting, and utilizing health information activities (Chen et al., 2018; Ranaweera, 2017) properly. In conclusion, the results of this research 
implies that biology teacher candidate students in Indonesia have low level of COVID-19 literacy.

\section{CONCLUSION}

This research has explored the level of COVID-19 literacy among biology teacher candidates. The results of the study informed that those teacher candidates had known COVID-19 before the disease entered Indonesia and social media was their main source of information. Most students have the wrong understanding about COVID-19, such as the role of vaccines, the types of symptoms, and the way COVID-19 is transmitted. Only a small proportion of those whose literacy were categorized in high level. Furthermore, students' year has no significant influence on their literacy.

The results of this study indicate that there are still many teacher candidates who have not been able to understand COVID-19 properly. Considering they are prospective biology teachers, they must be curious, selective, and critical of various information about biological phenomena that occur around them, including the COVID-19 outbreak. They are also expected to provide correct information about COVID19 to the communities around them. In line with the results, the campus should be responding appropriately and immediately. Education about COVID-19 to them needs to be improved and various lecture assignments are expected to be linked to COVID-19 knowledge.

\section{ACKNOWLEDGEMENT}

The author would like to thank Rector (Assoc. Prof. Dr. Fauzan, M.Pd.) and Vice Rector for Academic (Prof. Dr. Syamsul Arifin, M.Si.) and Director of Research and Community Service Directorate (Prof. Dr. Yus Mochamad Cholily M.Si.) of Universitas Muhammadiyah Malang for the moral and material support in this research.

\section{REFERENCES}

Adams, P. (2020). Classroom connection: Coronavirus misinformation already pandemic. Retrieved April 3, 2020, from News Literacy Project website: https:/ / newslit.org/ updates/coronavirusmisinformation-already-pandemic/

Al-Aufi, A. S., Al-Azri, H. M., \& Al-Hadi, N. A. (2017). Perceptions of Information Literacy Skills among Undergraduate Students in the Social Media Environment. International Information and Library Review, 49(3), 163-175. https://doi.org/10.1080/ 10572317.2017.1293416

Albright, A. E., \& Allen, R. S. (2018). HPV misconceptions among college students: The role of health literacy. Journal of Community Health, 43(6), 1192-1200. https://doi.org/10.1007/s10900-0180539-4
Andrea, S. (2020). Tips for fact checking information sharing about COVID-19 on social media. Retrieved April 2, 2020, from Virginia Tech Daily website: https:/ / vtnews.vt.edu/articles/2020/03/ socialmedia_expert.html

$\mathrm{Au}, \mathrm{R}$. (2020). Data literacy via COVID-19 - towards data science. Retrieved April 2, 2020, from Towards Data Science website: https:/ / towardsdatascience. com/data-literacy-via-covid-19-38965538f390

Ayaz-Alkaya, S., \& Terzi, H. (2019). Investigation of health literacy and affecting factors of nursing students. Nurse Education in Practice, 34(October 2018), 31-35. https://doi.org/10.1016/j.nepr.2018. 10.009

Bakhtiar, T. (2016). Optimal intervention strategies for cholera outbreak by education and chlorination. IOP Conference Series: Earth and Environmental Science, 31(1). https://doi.org/10.1088/17551315/31/1/012022

Balmer, D., King, A., Moloney, W., Moselen, E., \& Dixon, R. (2020). Nursing students and health literacy: The effect of region and programme level. Nurse Education in Practice, 42(October 2019). https:/ / doi.org/10.1016/j.nepr.2019.102688

Banik, P., \& Kumar, B. (2019). Impact of Information Literacy Skill on Students' Academic Performance in Bangladesh. International Journal of European Studies, 3(1), 27. https://doi.org/10.11648/j.ijes. 20190301.15

Barennes, H., Harimanana, A. N., Lorvongseng, S., Ongkhammy, S., \& Chu, C. (2010). Paradoxical risk perception and behaviours related to Avian Flu outbreak and education campaign, Laos. BMC Infectious Diseases, 10(March 2006). https:/ / doi.org /10.1186/1471-2334-10-294

Barsell, D. J., Everhart, R. S., Miadich, S. A., \& Trujillo, M. A. (2018). Examining Health Behaviors, Health Literacy, and Self-efficacy in College Students With Chronic Conditions. American Journal of Health Education, 49(5), 305-311. https:/ / doi.org/10.1080/ 19325037.2018.1486758

Batterham, R. W., Beauchamp, A., \& Osborne, R. H. (2016). Health literacy. In International Encyclopedia of Public Health (Second Edi, Vol. 3). https:/ / doi.org /10.1016/B978-0-12-803678-5.00190-9

Budd, S. (2020). Science literacy in a changing World: Covid-19 and CitySprouts Youth. Retrieved April 3, 2020, from CitySprouts website: https://www.citysprouts.org/news/2020/3/16/s cience-literacy-in-a-changing-world-covid-19-andcitysprouts-youth

Castro-Sánchez, E., Chang, P. W. S., Vila-Candel, R., Escobedo, A. A., \& Holmes, A. H. (2016). Health literacy and infectious diseases: Why does it 
matter? International Journal of Infectious Diseases, 43, 103-110. https:/ / doi.org/10.1016/j.ijid.2015.12.019

Chen, X., Hay, J. L., Waters, E. A., Kiviniemi, M. T., Biddle, C., Schofield, E., ... Orom, H. (2018). Health Literacy and Use and Trust in Health Information. Journal of Health Communication, 23(8), 724-734. https:/ / doi.org/10.1080/10810730.2018.1511658

Cucinotta, D., \& Vanelli, M. (2020). WHO declares COVID-19 a pandemic. Acta Bio-Medica: Atenei Parmensis, 91(1), 157-160. https:/ / doi.org/10.23750 /abm.v91i1.9397

DeLuca, E. (2020). Countries with lower literacy levels need different COVID-19 communication strategies. Retrieved April 1, 2020, from Translators without Borders website: https:/ / www.translators withoutborders.org/blog/literacy-levels-covid-19

Denuwara, H. M. B. H., \& Gunawardena, N. S. (2017). Level of health literacy and factors associated with it among school teachers in an education zone in Colombo, Sri Lanka. BMC Public Health, 17(1), 1-9. https: / / doi.org/10.1186/s12889-017-4543-x

DeWalt, D. A., Berkman, N. D., Sheridan, S., Lohr, K. N., \& Pignone, M. P. (2004). Literacy and health outcomes: A systematic review of the literature. Journal of General Internal Medicine, 19(12), 12281239. https://doi.org/10.1111/j.1525-1497.2004. 40153.x

Duong, T. Van, Sørensen, K., Pelikan, J. M., Van den Broucke, S., Lin, I. F., Lin, Y. C., ... Chang, P. W. (2018). Health-related behaviors moderate the association between age and self-reported health literacy among Taiwanese women. Women and Health, 58(6), 632-646. https://doi.org/10.1080/ 03630242.2017 .1333074

Elsborg, L., Krossdal, F., \& Kayser, L. (2017). Health literacy among Danish university students enrolled in health-related study programmes. Scandinavian Journal of Public Health, 45(8), 831-838. https: / / doi.org/10.1177/1403494817733356

Erich, A., \& Popescu, C. (2010). The impact of information literacy in the academic education environment. Library and Information Science, (14), 150-161. Retrieved from https://www.research gate.net/publication/265036131

Fendos, J. (2020, March 10). Lessons from South Korea's COVID-19 outbreak: The good, bad, and ugly. The Diplomat. Retrieved from https:/ / thediplomat.com /2020/03/lessons-from-south-koreas-covid-19. outbreak-the-good-bad-and-ugly/

Gazmararian, J. A., Curran, J. W., Parker, R. M., Bernhardt, J. M., \& DeBuono, B. A. (2005). Public health literacy in America: An ethical imperative. American Journal of Preventive Medicine, 28(3), 317322. https:/ / doi.org/10.1016/j.amepre.2004.11.004
Genlott, A. A., \& Grönlund, Å. (2013). Improving literacy skills through learning reading by writing: The iWTR method presented and tested. Computers and Education, 67, 98-104. https://doi.org/10.1016/ j.compedu.2013.03.007

George, T. P., \& DeCristofaro, C. (2018). Use of servicelearning to teach health literacy with online graduate nursing students. Nursing Education Perspectives, 39(3), 187-189. https://doi.org/ 10.1097/01.NEP.0000000000000231

Ghaddar, S. F., Valerio, M. A., Garcia, C. M., \& Hansen, L. (2012). Adolescent health literacy: The importance of credible sources for online health information. Journal of School Health, 82(1), 28-36. https://doi.org/10.1111/j.1746-1561.2011.00664.x

Griffey, R. T., Kennedy, S. K., McGownan, L., Goodman, M., \& Kaphingst, K. A. (2014). Is low health literacy associated with increased emergency department utilization and recidivism? Academic Emergency Medicine, 21(10), 1109-1115. https://doi.org/ $10.1111 /$ acem.12476

Guessoum, N. (2020, March 1). Coronavirus outbreak exposes need for scientific literacy. Arab News. Retrieved from https://www.arabnews.com/ node/1635281

Halsall, T., Garinger, C., Dixon, K., \& Forneris, T. (2019). Evaluation of a Social Media Strategy to Promote Mental Health Literacy and Help-Seeking in Youth. Journal of Consumer Health on the Internet, 23(1), 1338. https://doi.org/10.1080/15398285.2019.1571 301

Kaper, M. S., Reijneveld, S. A., van Es, F. D., de Zeeuw, J., Almansa, J., Koot, J. A. R., \& de Winter, A. F. (2020). Effectiveness of a comprehensive health literacy consultation skills training for undergraduate medical students: A randomized controlled trial. International Journal of Environmental Research and Public Health, 17(1), 1-15. https://doi.org/10.3390/ijerph17010081

Karimi, Z., Ashrafi-Rizi, H., Papi, A., Shahrzadi, L., \& Hassanzadeh, A. (2015). Effect of information literacy training course on information literacy skills of undergraduate students of Isfahan University of Medical Sciences based on ACRL standards. Journal of Education and Health Promotion, 4, 76. https:/ / doi.org/10.4103/2277-9531.171789

Karlsen, H., Mehli, L., Wahl, E., \& Staberg, R. L. (2015). Teaching outbreak investigation to undergraduate food technologists. British Food Journal, 117(2), 766778. https:/ / doi.org/10.1108/BFJ-02-2014-0062

Khan, M., Kazmi, S., Bashir, A., \& Siddique, N. (2020). COVID-19 infection: Origin, transmission, and characteristics of human coronaviruses. Journal of Advanced Research, 24, 91-98. https://doi.org/ 10.1016/j.jare.2020.03.005 
Khan, M. L., \& Idris, I. K. (2019). Recognise misinformation and verify before sharing: a reasoned action and information literacy perspective. Behaviour and Information Technology, 38(12), 1194-1212. https://doi.org/10.1080/ 0144929X.2019.1578828

Kickbusch, J., \& Maag, D. (2008). Health Literacy. International Encyclopedia of Public Health, 3, 204-211. Retrieved from http:/ / www.ilonakickbusch.com/ kickbusch-wAssets / docs/kickbusch-maag.pdf

Lai, H. R., Wu, D. M., Lee, P. H., \& Jhang, Y. S. (2018). Health literacy teaching beliefs, attitudes, efficacy, and intentions of middle school health and physical education teachers. Journal of School Health, 88(5), 350-358. https://doi.org/10.1111/josh.12615

Lamanauskas, V., \& Augiene, D. (2020). Identifying primary school teachers' health literacy. Journal of Turkish Science Education, 16(4), 451-466. https://doi.org/10.36681/tused.2020.0

Li, C., Yang, Y., \& Ren, L. (2020). Genetic evolution analysis of 2019 novel coronavirus and coronavirus from other species. Infection, Genetics and Evolution, 82(March), 1-3. https:/ / doi.org/10.1016/j.meegid. 2020.104285

Li, T., Lu, H., \& Zhang, W. (2020). Clinical observation and management of COVID-19 patients. Emerging Microbes $\mathcal{E}$ Infections, 9(1), 687-690. https:/ / doi.org /10.1080/22221751.2020.1741327

Lima, M. de F. G., Vasconcelos, E. M. R. de, \& Borba, A. K. de O. T. (2019). Instruments used to evaluate functional health literacy in elderly persons with chronic kidney disease: Integrative review. Revista Brasileira de Geriatria e Gerontologia, 22(3), 1-11. https://doi.org/10.1590/1981-22562019022.180198

Lin, Q., Zhao, S., Gao, D., Lou, Y., Yang, S., Musa, S. S., ... He, D. (2020). A conceptual model for the coronavirus disease 2019 (COVID-19) outbreak in Wuhan, China with individual reaction and governmental action. International Journal of Infectious Diseases, 93, 211-216. https:/ / doi.org/10.1016/j.ijid.2020.02.058

Lloyd-Sherlock, P. G., Kalache, A., McKee, M., Derbyshire, J., Geffen, L., Casas, F. G.-O., \& Gutierrez, L. M. (2020). WHO must prioritise the needs of older people in its response to the covid19 pandemic. BMJ (Clinical Research Ed.), 368(m1164), 1. https://doi.org/10.1136/bmj. m1164

Mackert, M., Champlin, S., \& Mabry-Flynn, A. (2017). Exploring college student health literacy: Do methods of measurement matter? Journal of Student Affairs Research and Practice, 54(3), 275-285. https:/ / doi.org/10.1080/19496591.2017.1289095

MacLeod, S., Musich, S., Gulyas, S., Cheng, Y., Tkatch, R., Cempellin, D., ... Yeh, C. S. (2017). The impact of inadequate health literacy on patient satisfaction, healthcare utilization, and expenditures among older adults. Geriatric Nursing, 38(4), 334-341. https:/ / doi.org/10.1016/j.gerinurse.2016.12.003

Mahase, E. (2020). Covid-19: WHO declares pandemic because of "alarming levels" of spread, severity, and inaction. BMJ (Clinical Research Ed.), 368(m1036), 1. https://doi.org/10.1136/bmj. $\mathrm{m} 1036$

Matthews, J. D. (2018). Health literacy among female university students in the United Arab Emirates. International Journal of Health Promotion and Education, 56(6), 298-308. https:/ / doi.org/10.1080/ 14635240.2018 .1536524

Maverick Insider. (2020). Virus literacy for beginners: Influenza and Covid-19. Retrieved April 1, 2010, from Daily Maverick website: https://www. dailymaverick.co.za/article/2020-03-12-virusliteracy-for-beginners-influenza-and-covid-19/

McCray, A. T. (2005). Promoting health literacy. Application OfInformation Technology, 12(2), 152-163. https:/ / doi.org/10.1197/jamia.M1687.Addressing

Mnatzaganian, C., Fricovsky, E., Best, B. M., \& Singh, R. F. (2017). An interactive, multifaceted approach to enhancing pharmacy students' health literacy knowledge and confidence. American Journal of Pharmaceutical Education, 81(2), 1-9. https://doi.org/10.5688/ajpe81232

Moon, S. J., \& Bai, S. Y. (2020). Components of digital literacy as predictors of youth civic engagement and the role of social media news attention: the case of Korea. Journal of Children and Media. https:/ / doi.org/10.1080/17482798.2020.1728700

Mullan, J., Burns, P., Weston, K., McLennan, P., Rich, W., Crowther, S., ... Osborne, R. (2017). Health literacy amongst health professional university students: A study using the health literacy questionnaire. Education Sciences, 7(2), 54. https://doi.org/ 10.3390 /educsci7020054

Newsome, C., Mallawaarachchi, I., Conklin, J., \& Ray, G. (2018). Health literacy of student pharmacists. Currents in Pharmacy Teaching and Learning, 10(3), 340-343. $\quad$ https://doi.org/10.1016/j.cptl.2017.11. 005

Nussbaumer, N. (2020). Six essential media literacy skills for COVID-19 and other crises. Retrieved April 3, 2020, from Buffalo Rising website: https:/ / www. buffalorising.com/2020/03/six-essential-medialiteracy-skills-for-covid-19-and-other-crises /

Oelze, M. (2019). \#HashtagPedagogies: Improving Literacy and Course Relevance through Social Media Metaphors. Change: The Magazine of Higher Learning, 51(6), 8-16. https://doi.org/10.1080/ 00091383.2019.1674076 
Okan, O., Sørensen, K., \& Messer, M. (2020). COVID-19: A guide to good practice on keeping people well informed. Retrieved April 2, 2020, from The Conversation website: https://theconversation. com/covid-19-a-guide-to-good-practice-onkeeping-people-well-informed-134046\#commentscontainer

Ozen, N., Bal Ozkaptan, B., Coskun, S., \& Terzioglu, F. (2019). Health literacy of nursing students and its effective factors. Nursing Forum, 54(3), 396-402. https://doi.org/10.1111/nuf.12346

Pampel, F. C., Krueger, P. M., \& Denney, J. T. (2010). Socioeconomic disparities in health behaviors. Annual Review of Sociology, 36, 349-370. https://doi.org/10.1146/annurev.soc.012809.1025 29

Paulsen, M., \& Taekke, J. (2013). Social media and teaching: Education in the new media environment. Defending Democracy., 1-13. Oslo and Akershus University College. Retrieved from https://pure. au.dk/portal/files/54508198/Social_Media_and_ Teaching._Taekke_and_Paulsen.pdf

Peters, R. J. G. (2017). Health literacy skills and the benefits of cardiovascular disease prevention. Netherlands Heart Journal, 25(7-8), 407-408. https: / / doi.org/10.1007/s12471-017-1001-4

Peterson, F. L., Cooper, R. J., \& Laird, J. M. (2001). Enhancing teacher health literacy in school health promotion: A vision for the new millennium. Journal of School Health, 71(4), 138-144. https:/ / doi. org/10.1111/j.1746-1561.2001.tb01311.x

Phan, T. (2020). Genetic diversity and evolution of SARSCoV-2. Infection, Genetics and Evolution, 81(February), 104260. https://doi.org/10.1016/ j.meegid.2020.104260

Pogreba-Brown, K., Ernst, K., \& Harris, R. (2012). Teaching epidemiology concepts experientially: A "real" foodborne outbreak in the classroom. Public Health Reports, 127(5), 549-555. https://doi.org/ $10.1177 / 003335491212700512$

Protheroe, J., Whittle, R., Bartlam, B., Estacio, E. V., Clark, L., \& Kurth, J. (2017). Health literacy, associated lifestyle and demographic factors in adult population of an English city: A crosssectional survey. Health Expectations, 20(1), 112-119. https://doi.org/10.1111/hex.12440

Rababah, J. A., Al-Hammouri, M. M., Drew, B. L., \& Aldalaykeh, M. (2019). Health literacy: Exploring disparities among college students. BMC Public Health, 19(1), 1-11. https://doi.org/10.1186/ s12889-019-7781-2

Ranaweera, P. (2017). Importance of information literacy skills for an information literate society. National Institute of Library $\mathcal{E}$ Information Sciences, University of Colombo, 1-13. https://doi.org/10.1017/ CBO9781107415324.004

Rong, H., Cheng, X., Garcia, J. M., Zhang, L., Lu, L., Fang, J., ... Chen, J. (2017). Survey of health literacy level and related influencing factors in military college students in Chongqing, China: A cross-sectional analysis. PLoS ONE, 12(5), 1-14. https://doi.org/ 10.1371/journal.pone.0177776

Rosario, C., Modeste, N., Dos Santos, H., Handysides, D., Gamboa-Maldonado, T., \& Boyd, K. (2017). An examination of ecological predictors of health literacy in black college students. Journal of American College Health, 65(6), 423-431. https:/ / doi.org/10.1080/07448481.2017.1341894

Runk, L., Durham, J., Vongxay, V., \& Sychareun, V. (2017). Measuring health literacy in university students in Vientiane, Lao PDR. Health Promotion International, 32(2), 360-368. https://doi.org/ 10.1093/heapro/daw087

Schwartz, S. (2020, March 6). Teaching about coronavirus: 3 lesson plans for science, Mmath, and media literacy. Teaching Now - Education Week Teacher. Retrieved from http:/ / blogs.edweek.org/ teachers/teaching_now/2020/03/teaching_about _coronavirus_3_lesson_plans_for_science_math_a nd_media_literacy.html

Shao, X., \& Purpur, G. (2016). Effects of Information Literacy Skills on Student Writing and Course Performance. Journal of Academic Librarianship, 42(6), 670-678. https://doi.org/10.1016/j.acalib. 2016.08 .006

Sohrabi, C., Alsafi, Z., Neill, N. O., Khan, M., Kerwan, A., Al-jabir, A., ... Agha, R. (2020). World Health Organization declares global emergency: A review of the 2019 novel coronavirus (COVID-19). International Journal of Surgery, 76, 71-76. https:/ / doi.org/10.1016/j.ijsu.2020.02.034

Soleymani, M. R. (2014). Investigating the relationship between information literacy and academic performance among students. Journal of Education and Health Promotion, 3, 95. https://doi.org/ 10.4103/2277-9531.139677

Sørensen, K. (2020). Covid-19: Digital health literacy is a key to saving time, costs and lives. Retrieved April 2, 2020, from ICT\&health website: https:/ / www. ictandhealth.com/news / covid-19-digital-healthliteracy-is-a-key-to-saving-time-costs-and-lives /

Sørensen, K., Van Den Broucke, S., Fullam, J., Doyle, G., Pelikan, J., Slonska, Z., \& Brand, H. (2012). Health literacy and public health: A systematic review and integration of definitions and models. BMC Public Health, 12(1), 1-13. https://doi.org/10.1186/14712458-12-80

Sormunen, M., Goranskaya, S., Kirilina, V., Bykachev, K., \& Tossavainen, K. (2018). Home and school 
responsibilities for children's health literacy development: the views of Finnish and Russian parents and teachers. Russian Journal of Communication, 10(1), 70-90. https://doi.org/ 10.1080/19409419.2017.1381570

Štefková, G., Čepová, E., Kolarčik, P., \& Madarasová Gecková, A. (2018). The level of health literacy of students at medical faculties. Kontakt, 20(4), e363e369. https:// doi.org/10.1016/j.kontakt.2018.10. 011

Su, L., Ma, X., Yu, H., Zhang, Z., Bian, P., Han, Y., ... Gai, Z. (2020). The different clinical characteristics of corona virus disease cases between children and their families in China - the character of children with COVID-19. Emerging Microbes $\mathcal{E}$ Infections, 9(1), 707-713. https://doi.org/10.1080/22221751. 2020.1744483

Sukys, S., Cesnaitiene, V. J., \& Ossowsky, Z. M. (2017). Is health education at university associated with students' health literacy? evidence from crosssectional study applying HLS-EU-Q. BioMed Research International, 2017. https://doi.org/ $10.1155 / 2017 / 8516843$

Sykes, S., Wills, J., Rowlands, G., \& Popple, K. (2013). Understanding critical health literacy: a concept analysis. BMC Public Health, 13(1), 150. https:/ / doi.org/10.1186/1471-2458-13-150

Tavakoly Sany, S. B., Peyman, N., Zadehahmad, Z., Ferns, G., \& Doosti, H. (2019). Effect of educational interventions on health literacy in patients with heart failure. International Journal of Health Promotion and Education, 57(1), 23-36. https:/ / doi.org/10.1080/14635240.2018.1545597

Tezci, E., \& İçen, M. (2017). High school students' social media usage habits. Journal of Education and Practice, 8(27), 99-108.

Tully, M., Vraga, E. K., \& Bode, L. (2020). Designing and Testing News Literacy Messages for Social Media. Mass Communication and Society, 23(1), 22-46. https:/ / doi.org/10.1080/15205436.2019.1604970
Uysal, N., Ceylan, E., \& Koç, A. (2020). Health literacy level and influencing factors in university students. Health and Social Care in the Community, 28(2), 505511. https:/ / doi.org/10.1111/hsc.12883

Vamos, S., Okan, O., Sentell, T., \& Rootman, I. (2020). Making a case for "Education for health literacy": An international perspective. International Journal of Environmental Research and Public Health, 17(1436), 1-18. https:/ / doi.org/10.3390/ijerph17041436

Vraga, E. K., \& Tully, M. (2019). News literacy, social media behaviors, and skepticism toward information on social media. Information, Communication $\mathcal{E}$ Society, 1-17. https://doi.org/ 10.1080/1369118x.2019.1637445

Wang, H., Wang, Z., Dong, Y., Chang, R., Xu, C., Yu, X., ... Cai, Y. (2020). Phase-adjusted estimation of the number of Coronavirus Disease 2019 cases in Wuhan, China. Cell Discovery, 6(1), 4-11. https:/ / doi.org/10.1038/s41421-020-0148-0

Watkins, J. (2020). Preventing a covid-19 pandemic. The BMJ, 368(February), 1-2. https://doi.org/10.1136/ bmj.m810

Wolf, M. S., Curtis, L. M., Wilson, E. A. H., Revelle, W., Waite, K. R., Smith, S. G., .. Baker, D. W. (2012). Literacy, cognitive function, and health: Results of the LitCog study. Journal of General Internal Medicine, 27(10), 1300-1307. https://doi.org/ $10.1007 /$ s11606-012-2079-4

Worldometers. (2020). COVID-19 coronavirus pandemic. Retrieved April 7, 2020, from Coronavirus website: https:/ / www.worldometers. info/coronavirus/

Yang, J., Park, E. C., Lee, S. A., \& Lee, S. G. (2019). Associations between hand hygiene education and self-reported hand-washing behaviors among Korean adults during MERS-CoV outbreak. Health Education and Behavior, 46(1), 157-164. https:/ / doi.org/10.1177/1090198118783829

\section{http://www.ejmste.com}

